\title{
Anti-candidal activity of Aspergillus flavus IBRL-C8, an endophytic fungus isolated from Cassia siamea Lamk leaf
}

\author{
Darah Ibrahim, Nurhaida, Lim Sheh Hong* \\ Industrial Biotechnology Research Laboratory, School of Biological Sciences, Universiti Sains Malaysia, 11800 Penang, Malaysia.
}

\begin{tabular}{|c|c|}
\hline ARTICLE INFO & ABSTRACT \\
\hline $\begin{array}{l}\text { Article history: } \\
\text { Received on: } 18 / 10 / 2017 \\
\text { Accepted on: } 24 / 12 / 2017 \\
\text { Available online: } 27 / 02 / 2018\end{array}$ & $\begin{array}{l}\text { An endophytic fungus, Aspergillus flavus IBRL-C } 8 \text { was isolated from leaf of a medicinal plant Cassia siamea Lamk. } \\
\text { This isolated fungus was cultivated in the medium which has enriched with water extract of host plant then incubated } \\
\text { at } 30^{\circ} \mathrm{C} \text { with } 120 \mathrm{rpm} \text { for } 20 \text { days. After incubation period, the fermentative broth medium which contained the } \\
\text { extracellular compounds secreted by the fungal biomass into the medium will be extracted with ethyl acetate. This } \\
\text { extract showed significant inhibition zone against Candida albicans cells. The minimal inhibitory concentration }\end{array}$ \\
\hline $\begin{array}{l}\text { Key words: } \\
\text { Anticandidal activity, } \\
\text { Candida albican, Cassia } \\
\text { siamea, Endophytic fungus, } \\
\text { Minimum inhibitory concen- } \\
\text { tration }\end{array}$ & $\begin{array}{l}\text { (MIC) showed } 1.0 \mathrm{mg} / \mathrm{mL} \text { and its exhibited yeastocidal activity. The time-kill curve study was performed at three } \\
\text { different extract concentrations ( } 1 / 2 \mathrm{MIC} \text {, MIC and } 2 \mathrm{MIC} \text { ) and the results showed that the } C \text {. albicans cell growth } \\
\text { was concentration dependent. The extract concentration lower than MIC value showed yeastostatic activity and } \\
\text { at concentration higher than the MIC value it showed yeastocidal activity. Further detail of the effect of the ethyl } \\
\text { acetate extract on the } C \text {. albicans cell was observed from the scanning electron microscopy and transmission electron } \\
\text { microscopy photomicrographs which revealed severity of morphological deterioration experienced by the extract } \\
\text { treated cells were beyond repair. }\end{array}$ \\
\hline
\end{tabular}

\section{INTRODUCTION}

There has been an alarming increase in life threatening systemic fungal and yeast infections of varying types which are observed in immunosuppressed and immunocompromised person such as AIDS, cancer, and transplant patients. Yeasts especially the Candida albicans has emerged as significant pathogens in recent decades as a consequence of increasing numbers and population of immunocompromised patients (Fostel and Latey, 2000; Kim and Sudbery, 2011). As a result, they have become a main cause of death in patients who treated for malignant diseases and emerging immune deficiency diseases (Xiang et al., 2013). Furthermore, management of their infections have become more complex due to lack of effective antifungal drugs, drug safety problems, side effects, and etc (Pfeiffer et al., 2012). As a result of the increasing prevalence of resistant fungal and yeast strains, Levy (2005) has reported endophytes are a new finding for potentially useful medicinal compounds to overcome the drug resistance issue.

\section{${ }^{*}$ Corresponding Author}

Lim Sheh Hong, Industrial Biotechnology Research Laboratory, School of Biological Sciences, Universiti Sains Malaysia, 11800 Penang, Malaysia. E-mail: limshehhong77@gmail.com
Endophytes are refer to microorganisms grow in intercellular of healthy host tissues and not causing symptoms (Strobel, 2003; Yu et al., 2010). In fact, the endophytic fungi also as a source of secondary metabolites that has been proven useful in drug discovery (Yan et al., 2011). Endophyes able to produce some pharmacologically compounds and which having diverse structural groups and showing antimicrobial activity, anticancer, antioxidant, insecticide, and etc (Demain, 1999; Tan and Zou, 2001; Liang et al. 2012; Idris et al. 2013; Gherbawy and Gashgari, 2014; Bhardwaj et al. 2015).

Due to the novel secondary metabolite of endophytic fungi, therefore this study was carried out to evaluate the endophytic fungus $A$. flavus IBRL-C8, that possessed bioactive agents could be a new anti-candidal source.

\section{MATERIALS AND METHODS}

\section{Maintenance of Aspergillus flavus IBRL-C8}

The endophytic fungus previously isolated from the leaf of Cassia siamea Lamk was provided by the culture collection of the Industrial Biotechnology Research Laboratory (IBRL), School of Biological Sciences, Universiti Sains Malaysia, Penang, Malaysia. The isolate was cultivated and maintained on potato dextrose agar (PDA) enriched with powdered host plant materials 
$(10 \mathrm{~g} / \mathrm{L})$ and incubated at $30^{\circ} \mathrm{C}$. The viability of the fungus isolate was done every month by sub culturing.

\section{Culture medium}

Yeast extract sucrose broth (sucrose $40 \mathrm{~g} / \mathrm{L}$, yeast extract $20 \mathrm{~g} / \mathrm{L}$ and magnesium sulphate $0.5 \mathrm{~g} / \mathrm{L}$ ) and aqueous extract of $C$. siamea leaf was used to cultivate the A. flavus IBRL-C8 in flask system. The host plant extract was obtained by boiling $10 \mathrm{~g}$ of the powdered leaf in $500 \mathrm{~mL}$ distilled water for 30 minutes. The mixture was then filtered through Whatman filter paper and the filtrate was mixed with freshly prepared culture medium, followed by autoclaving at $121^{\circ} \mathrm{C}$ for 15 minutes.

\section{Cultivation and extraction of secondary metabolites}

The mycelial agar plug with $1.0 \mathrm{~cm}$ in diameter and 4.0 $\mathrm{mm}$ thickness was cut from the 7 days old fungal culture. The two plugs introduced into $250 \mathrm{~mL}$ Erlenmeyer flask which containing $100 \mathrm{~mL}$ of the culture medium and incubated at $30^{\circ} \mathrm{C}$ with 120 rpm of agitation speed for 20 days. After the incubation time, the culture was centrifuged at $5311 \mathrm{~g}$ to separate the fungal biomass from the broth. The filtered broth was extracted for 3 times with ethyl acetate with the ratio of $1: 1(\mathrm{v} / \mathrm{v})$. The extract was then evaporated to dryness using a rotary evaporator under reduced pressure until crude ethyl acetate extract paste obtained. The fungal biomass was freeze-dried and macerated in methanol with the ratio 1:50 (w/v) for overnight. The mixture was filtered using Whatman filter paper (No 1). Methanolic extract was concentrated under reduced pressure by using a rotary evaporator until crude methanolic extract paste formed.

\section{Test microorganisms}

The clinical isolate Candida albicans culture was obtained from the culture collection of IBRL, School of Biological Sciences, Universiti Sains Malaysia, Penang, Malaysia. The culture was kept as $20 \%$ glycerol stock at $-20^{\circ} \mathrm{C}$. The culture was resubculture monthly on Sabouraud dextrose agar (SDA) and incubated at $37^{\circ} \mathrm{C}$ for $24-48$ hours.

C. albican's inoculum was prepared by picking 3-5 of distinct pure colonies from a 24-48 hours old culture on SDA plate. Colonies were dispersed in a universal bottle containing 10 $\mathrm{ml}$ of sterile physiological saline $(0.85 \% \mathrm{w} / \mathrm{v})$. The mixture was vortex for homogenization and its turbidity was adjusted virtually which match the turbidity of a $0.5 \mathrm{Mc}$ Farland standard.

\section{Disc diffusion susceptibility assay}

The assay was performed according to the method stated in Clinical and Laboratory Standard Institute (CLSI) standard M100-S16 (CLSI, 2006) and M100-S22 (CLSI, 2012). The $5 \%$ dimethyl sulfoxide (DMSO) was used to dissolve the crude extract. Tested yeast was streak on the surface of the SDA plate by using sterile cotton swab. The sterile $6.0 \mathrm{~mm}$ diameter of antibiotic discs (free of antibiotic) were impregnated with $20 \mu \mathrm{L}$ of the ethyl acetate and methanolic extracts $(20 \mathrm{mg} / \mathrm{mL})$ and airdried before placing them on the seeded agar plate. Ketoconazole $(30 \mu \mathrm{L} / \mathrm{mL})$ was used as positive control and 5\% DMSO solution was used as a negative control. The plates were incubated at $37^{\circ} \mathrm{C}$ for 24 hours in incubator. The anti-candidal activity was identified by measuring the diameter of the inhibition zones formed around the disc. The experiments were carried out in triplicate.

\section{Determination of MIC and MYC}

MIC was carried out by using broth microdilution assay in sterile 96-well microtiter plate (Tong et al., 2012). Sterile RPMI 1640 containing $0.2 \%$ dextrose buffered, $0.165 \mathrm{M}$ 3 -(N-morpholino) propanesulfonic acid (MOPS) at $\mathrm{pH} 7$ with $25^{\circ} \mathrm{C}$ was used. The prepared inoculum was diluted by sterile saline and adjusted to the inoculum size of $5 \times 10^{4} \mathrm{CFU} / \mathrm{mL}$. The fungal extracts were dissolved in 5\% DMSO. A serial two-fold dilution of the extracts was applied to get concentrations ranged from $2.0000-0.0157 \mathrm{mg} / \mathrm{mL}$. The well with $5 \%$ DMSO and inoculum was used as a control. The plates were incubated at $37^{\circ} \mathrm{C}$ for 24 hours on a rotary shaker. After the incubation period, 40 $\mu \mathrm{L}$ of $0.2 \mathrm{mg} / \mathrm{mL}$ p-iodonitrotetrazolium violet salt (INT, Sigma) was added into each well to act as growth indicator. The purple color of INT showed the cell growth occurred. The MIC value $(1.0 \mathrm{mg} / \mathrm{mL})$ was the lowest concentration of extract that inhibited the growth of yeast. MYC value of the extract was determined by taken out $100 \mu \mathrm{L}$ of the sample from each well and suitably diluted before streaking on SDA plate to judge the viability (Tong et al., 2012). The MYC was recorded as the lowest concentration of extract that killed $99.9 \%$ growth compared to control.

\section{Growth profile of Candida albicans cells}

The growth profile was conducted in $50 \mathrm{~mL}$ Erlenmeyer flask containing $20 \mathrm{~mL}$ sterile RPMI 1640 medium. The $C$. albicans suspension was prepared as described by CLSI (2006). Few 16-24 hours old C. albicans colonies were picked up and then aseptically inoculated into the medium and incubated at $37^{\circ} \mathrm{C}$ with agitation speed at $150 \mathrm{rpm}$ for 16 to 18 hours. The turbidity of the cells log phase was read using a spectrophotometer (Thermo, Massachusetts) at a wavelength of $625 \mathrm{~nm}$. The ethyl acetate extract was adjusted to $1 / 2 \mathrm{MIC}(0.50 \mathrm{mg} / \mathrm{mL})$, MIC susceptibility breakpoint $(1.00 \mathrm{mg} / \mathrm{mL})$ and $2 \mathrm{MIC}(2.00 \mathrm{mg} / \mathrm{mL})$. The culture flasks were incubated at $37^{\circ} \mathrm{C}$ with $150 \mathrm{rpm}$ on shaker. At predetermined time periods $(0,4,8 \ldots 48$ hour $)$, a $100 \mu \mathrm{L}$ aliquot from each treatment mixture was withdrawn and the viable cell count was carried out by inoculating the diluted sample on SDA plates. The number of colonies grown on the plates (30-300 colonies only) were recorded. The population growth of the yeast cells that caused by the extract was analyzed by plotting logarithm of viable cells $\left(\log _{10} \mathrm{CFU} / \mathrm{mL}\right)$ versus incubation time.

\section{Structural degeneration of ethyl acetate extract treated on $C$. albicans cells}

The $C$. albicans suspension was prepared as described previously. The suspension was then added to the extract stock solution to have the final concentration in the flask at MIC value $(1.00 \mathrm{mg} / \mathrm{mL})$. The inoculated flasks were incubated at $37^{\circ} \mathrm{C}$ and $150 \mathrm{rpm}$ of agitation speed. The cultures were harvested at 0 and 36 hours of incubation period and proceed for scanning (SEM) and transmission (TEM) electron microscopy studies as described previously by Borges et al. (1989) and Mares (1989). The prepared samples were then viewed under SEM (Leica Cambridge, S-360, UK) and TEM (LIBRA@120 EFTEM, Germany).

\section{Statistical analysis}

Student $t$-test was used for comparing the effect of ethyl acetate extract on $C$. albicans cells against control using SPSS Version 12.0. Statistical significance was assumed as $p<0.05$. 


\section{RESULTS}

Table 1 showed the anti-candidal activity of an endophytic fungus isolated from leaf of $C$. siamea by disc diffusion susceptibility assay. The results demonstrated that the ethyl acetate extract which contained the compounds secreted extracellularly into the fermentation medium by the fungus exhibited significant anti-candidal activity with $28.3 \pm 2.4 \mathrm{~mm}$ of inhibition zone. However, there was no anti-candidal activity showed by the methanolic extract which was extracted from the fungal biomass, meaning that there was no anti-candidal activity detected intracellularly.

Table 1: Anti-candidal activity of the crude ethyl acetate and methanolic extracts of A. flavus IBRL-C8.

\begin{tabular}{ccccc}
\hline \multirow{2}{*}{$\begin{array}{c}\text { Tested } \\
\text { yeast }\end{array}$} & \multicolumn{4}{c}{ Diameter of Inhibition zone (mm) } \\
\cline { 2 - 5 } & $\begin{array}{c}\text { Ethyl acetate } \\
\text { extract }\end{array}$ & $\begin{array}{c}\text { Methanolic } \\
\text { extract }\end{array}$ & $\begin{array}{c}\text { Positive } \\
\text { control }\end{array}$ & $\begin{array}{c}\text { Negative } \\
\text { control }\end{array}$ \\
\hline C. albicans & $28.3 \pm 2.4$ & - & $29.3 \pm 0.9$ & - \\
\hline
\end{tabular}

Positive control: $30 \mu \mathrm{g} / \mathrm{mL}$ Ketoconazole; Negative control: $5 \%$ DMSO

The MIC and MYC values of the ethyl acetate extract against $C$. albicans were stated in Table 2. For most of the microorganisms, the MYC was significantly higher than the MIC values. This condition indicated that the concentration of the extract needs to be significantly increased to kill the cells. This activity of the extract can be considered as bactericidal because the ratios of MYC/MIC were $\leq 4$ (Table 2). The results obtained also showed that broth microdilution assay was more sensitive and provided useful information in evaluating the susceptibility of the extract against the microorganisms.

Table 2: MIC and MYC values $(\mathrm{mg} / \mathrm{mL})$ of ethyl acetate extract from A. flavus IBRL-C8.

\begin{tabular}{cccc}
\hline Test microorganisms & MIC & MYC & Ratio of MYC:MIC \\
C. albicans & 1.000 & 4.000 & 4 (Bactericidal) \\
\hline
\end{tabular}

Figure 1 shows the time-kill study of ethyl acetate extract from $A$. flavus IBRL-C8 against $C$. albicans. The results revealed that at the $1 / 2 \mathrm{MIC}$ value $(0.50 \mathrm{mg} / \mathrm{mL})$ the effect was yeastostatic but at the MIC $(1.00 \mathrm{mg} / \mathrm{mL})$ and $2 \mathrm{MIC}(2.00 \mathrm{mg} /$ $\mathrm{mL}$ ) were yeastocidal. There was a dropped in OD after 24 hours of cultivation (at 2MIC). The results also indicated the potency of the extract as a candidate for anti-candidal agent against $C$. albicans.



Fig. 1: Time-kill curve of ethyl acetate extract from A. flavus IBRL-C8 against C. albicans
In order to have a detail observation of what actually happened to the $C$. albicans cells during the exposure to the extract in time-kill curve, SEM and TEM photomicrographs were studied. Figure 2 shows the SEM photomicrographs of the effect of the ethyl acetate extract produced by an endophytic $A$. flavus IBRL-C8 against $C$. albicans cells. Figure 2A shows the untreated or control cells with oval and smooth cells in appearance and some budding. On the other hand, after 36 hours of exposure to the extract (Figure 2B), remarkable morphological and distinct feature changes of the cells occurred where there were invaginations and cavitation formed on the cells surfaces and shrunken cells were also observed. The results shown that the cells had undergone severe morphological changed and cytological alterations. These damaged cells were lost their metabolic functions.
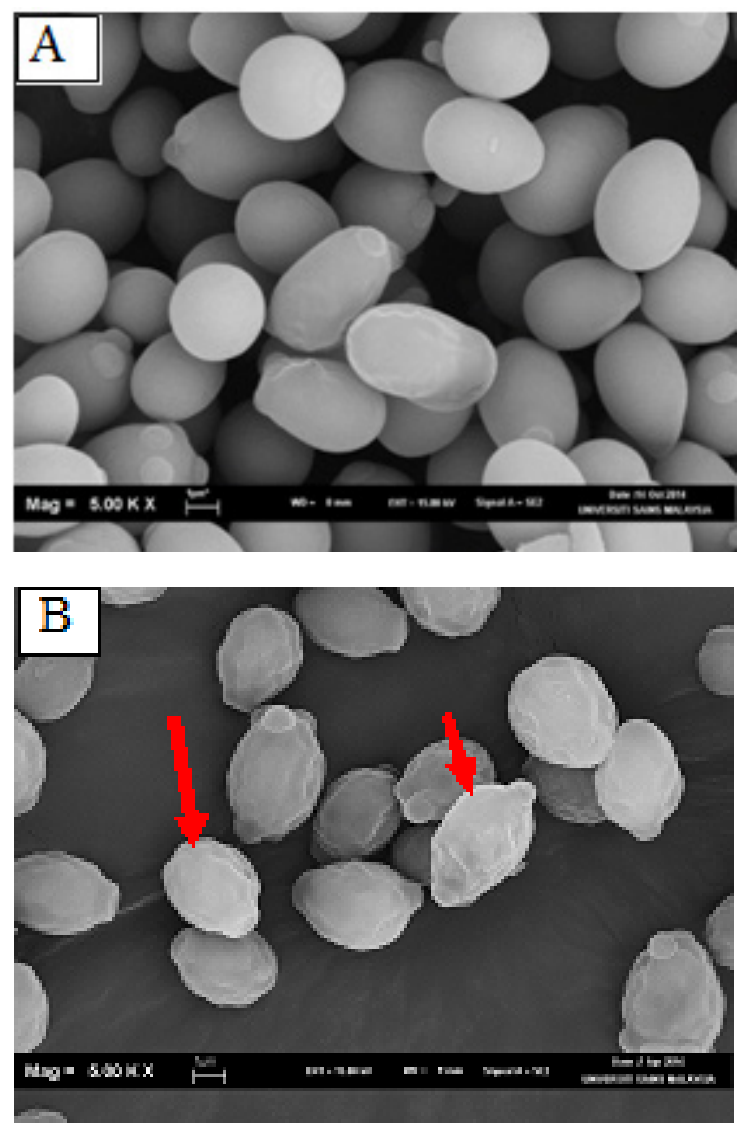

Fig. 2: SEM photomicrographs of C. albicans cells. (A) untreated cell (control) and (B) treated cell with $A$. flavus IBRL-C8 ethyl acetate extract, at MIC value $(1.0 \mathrm{mg} / \mathrm{mL})$ and 36 hours of exposure time. Magnification 5000X. Arrows show the morphological and distinct feature changes occurred on the cells.

The Figure 3A shows an untreated or control cells with the typical structure of $C$. albicans cells. The normal cytoplasm contains element of cell membrane system and enveloped by a typical cell wall of yeast cells was seen. On the other hand, the 36 hour extract treated cells (Figure 3B) shows the disposition and alterations of the cell. The cytoplasmic volume decreased and there was deformed or stunted budding formation. It was obviously seen that the cells faced severe disorganization inside the cells which then led to collapse of the cells. The 36 hour treated cells also displayed disintegration of the cell membrane, disorganized cytoplasm and its organelles. 

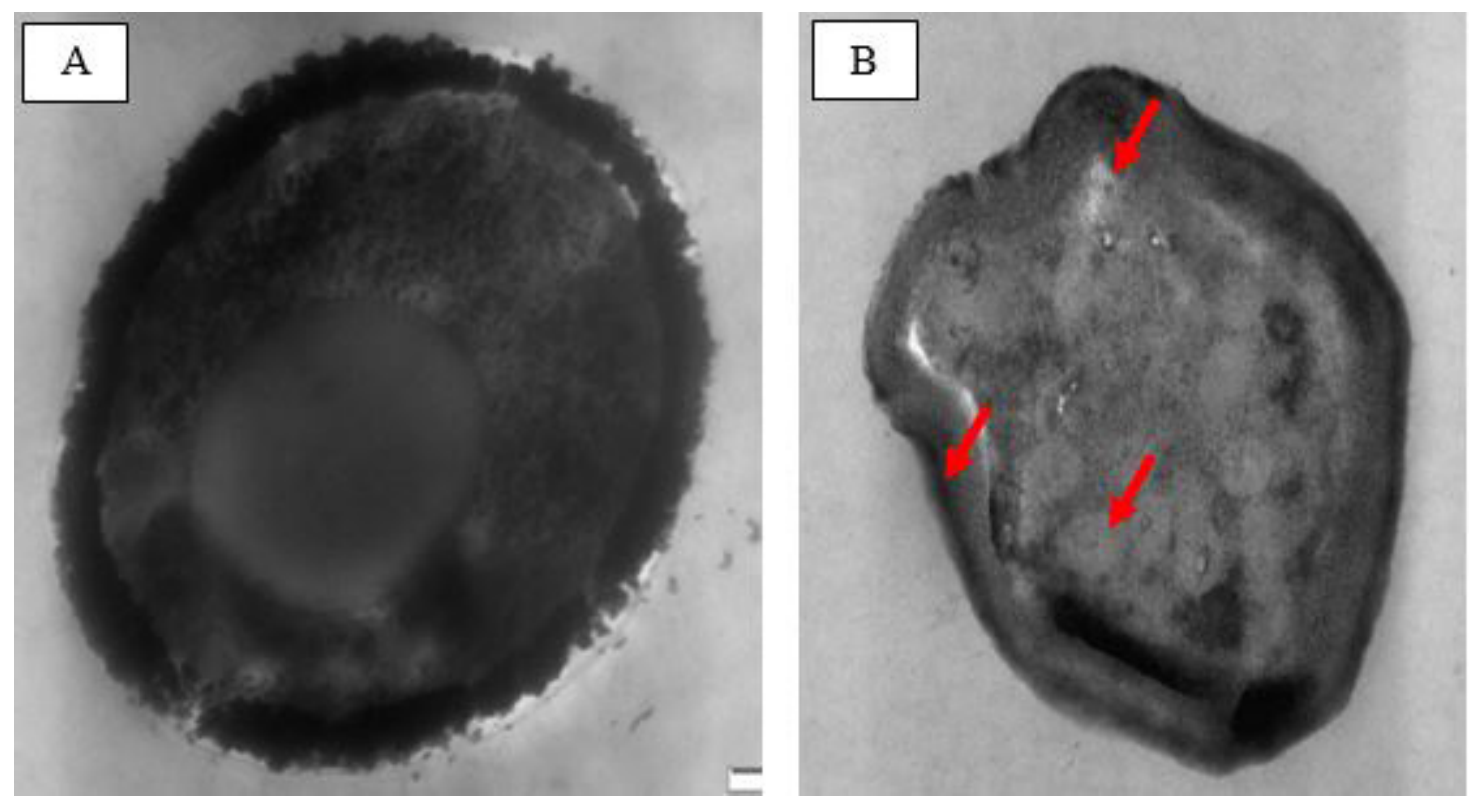

Fig. 3: TEM photomicrographs of C. albicans cells. (A) untreated cells (control) and (B) treated cells with A. flavus IBRL-C8 ethyl acetate extract, at MIC value (1.0 $\mathrm{mg} / \mathrm{mL}$ ) and 36 hours of exposure time. Arrows show disintegrity of the cell membrane, disorganized cytoplasm and its organelles.

\section{DISCUSSION}

The appearance of drug-resistant strains and toxic effects that limit the dose have prevented antifungal treatments, especially infections caused by C. albicans (Quindos, 2014; Yapar, 2014). Moreover, candida species are opportunistic pathogens causing candidiasis. Invasive Candidiasis is a life-threatening infection among immunocompromised patients. Even though plenty of anti-candidal drugs are available to treat superficial and systemic candidiasis, only three classes of drugs are widely used such as the polyenes, azoles and flucytosine. However, the fungal infections still continue to be one of the most common problem associated with the daily life (Arendrup, 2014). Therefore, new reliable antifungal drugs are very much sought for and one of the antifungal sources is from endophytic fungi which residing in many established medicinal herbal plants. There is a growing interest to find new, natural compounds with anti-candidal activity from endophytic fungi because most Candida species show reduced sensitivity towards traditional antifungal compounds (Papon et al., 2013).

The present study has shown that the fermentation broth of a fungal isolate A. flavus IBRL-C8 which was isolated from leaf of Cassia siamea possess anti-candidal activity. The results also revealed that the MIC and MYC values for the clinical isolate $C$. albicans were 1.00 and $4.00 \mathrm{mg} / \mathrm{mL}$, respectively. Levison (2000) stated that the minimal lethality concentration value for bactericidal drugs is usually not more than four-fold higher than their MIC values. Hence, the activity of the extract can be considered as fungicidal because the ratios of MYC/MIC were $\leq 4$ (Table 2). It is clinically more important in any microbial treatment to find the cidal than the static activity, especially in immunocompromised patients.

C. albicans is a common pathogen found inside human body and it is also usual seen from the immune deficient patients (Yapar, 2014). In non-pathogenic phase the cell remains in oval shape with buddings form but while changing into a pathogen the elongated cell was seen and known as pseudohyphae (Sudbery,
2011). The presence of pseudohyphae and budding in C. albicans is always associated to virulence and pathogenicity, and both of them may involve in the development of diseases.

Hence, many investigations have been done to search for new compounds with anti-candidal activity especially from natural sources such as endophytic fungi. Since the secondary metabolites of endophytic fungi has reported with many biological activities (Strobel, 2003), many studies have been carried out. Our results also showed a significant anti-candidal activity exhibited by the ethyl acetate extract of $A$. flavus IBRL-C8. Among the other researchers who reported the anti-candidal activity by endophytic fungi are Tong et al. (2017) who reported the isolation of a novel anticandidal compound (keton derivative, 2,3-hydroxy-5-methoxy hex-5-ene-2,4-dione) from an endophytic Diaporthe sp. ED2 was isolated from the leaf of Orthosiphon stamineus.

Based on both SEM and TEM photomicrographs, intriguing results were seen where the morphological changes experienced by the $C$. albicans cells reconfirmed the anti-candidal activity possessed by the extract. Physical changes of growing budding cells affected by the extract suggested that the extract inhibit the cell wall components. Thus, it is the reasonably presumptive that inhibition by the extract of fungal cell wall can induce abnormal cell-wall formation for normal yeast. In fact, the major morphological changes produced by growth-inhibitory concentrations are caused by the inhibition of yeast cell wall formation.

Yeast and fungi have similar basic structures of eukarytic cells or most likely to plant cell walls but different in chemical components. Their cell walls consist of two layers structure such as polysaccharides, alkali-insoluble $\beta$-glucans, alkali-soluble $\beta$-glucans, mannan and minor chitin (Nguyen et al., 1998; AguilarUscanga et al., 2003; Luo et al., 2015). The chitin is arranged in the form of microfibrillar bundles. Even though yeast and fungi are lacking in cellulose but they have other polysaccharide such as chitosans, galactosans and mannans as well, which may replace chitin in some of the fungal cell walls and form rigid fungal cell 
walls together with lipids, proteins, polyphosphates and inorganic ions (Madigan et al., 2009).

Many reports have been published by various researchers on the possible mechanism or mode of action of the extracts on the yeast and fungal cells. Majority observed the effects of extract on the inhibition of the fungal cell wall and fungal membrane structure, finally caused in cell lysis (Selitrennikoff, 2001). The results from this study revealed that the ethyl acetate extract affected the cell wall biosynthesis as well as the interference in cell membrane permeability. The results are comparable to Darah et al. (2013) who showed that the pyroligneous acid of Rhizophora apiculata affected the cavitation of $C$. albicans cells which lead to cell shrinkage and cell wall disruption and inhibited the growth. Due to the main metabolic systems of cell depends on the integrity of the cell membranes; thus the presence of extract affected cell membranes and particularly altered the organelles of cell as well (Bush, 2012).

\section{CONCLUSION}

The results showed the ethyl acetate extract of $A$. flavus IBRL-C8, a fungal endophyte isolated from leaf of $C$. siamea exhibited significance anti-candidal effects on $C$. albicans cells and could be a good candidate for antifungal drugs. The morphofunctional disintegration of fungal cell components as well as the interference of the cell membrane permeability may be the probable mechanism of action that leads to cell lysis.

\section{COMPETING INTERESTS}

Authors have declared that no competing interests exist.

\section{ACKNOWLEDGEMENT}

The authors are thankful to Universiti Sains Malaysia for awarding the RUI research grant scheme (ac: 1001/ PBIOLOGI/811326) to support this research work.

\section{REFERENCES}

Aguilar-Uscanga B, Francois JM. A study of the yeast cell wall composition and structure in response to growth conditions and mode of cultivation. Lett Appl Microbiol 2003; 37: 268-274.

Arendrup MC. Update on antifungal resistance in Aspergillus and Candida. Clin Microbiol Infect 2014; 20(6): 42-48.

Bhardwaj A, Sharma D, Jodan N, Agrawal PK. Antimicrobial and phytochemical screening of endophytic fungi isolated from spikes of Pinus roxburghii. Arch Clin Microbiol 2015; 6(3):1-9.

Borges M, De Ven MA, Van Cutsem J. Structural degeneration of Aspergillus fumigatus after exposure to saperconazole. J Med Vet Mycol 1989; 27: 381-389.

Bush K. Antimicrobial agents targeting bacterial cell walls and cell membranes. Rev Sci Technol 2012; 31(1): 43-56.

Clinical and Laboratory Standards Institute. 2006. Performance standards for antimicrobial susceptibility testing; 16th informational supplement. M100-S16. Clinical and Laboratory Standards Institute, Wayne, PA.

Clinical Laboratory Standards Institute. 2012. Performance standards for antimicrobial susceptibility testing; 22nd informational supplement. Document M100-S22. Clinical Laboratory Standards Institute, Wayne, PA.

Darah I, Jain K, Lim SH, Wendy R. Efficacy of pyroligneus acid from Rhizophora apiculate on pathogenic Candida albicans. J Appl Pharma Sci 2013; 3(7): 7-13

Demain AL. Pharmaceutically active secondary metabolites of microorganisms. Appl Microbiol Biotechnol 1999; 52: 455-463.

Fostel JM, Latey PA. Emerging novel antifungal agents. Drug Discovery Today 2000; 5(1): 25-32.

Gherbawy Y, Gashgari R. Molecular characterization of endophytic fungi from Calotropis procera plants in Taif region
(Saudi Arabia) and their antifungal activities. Plant Biosyst 2014; 148(6):1085-1092.

Idris A, Ietidal A, Idris M. Antibacterial activity of endophytic fungi extracts from the medicinal plant Kigelia africana. Egypt Acad J Biol Sci 2013; 5(1):1-9.

Kim J, Sudbery P. Candida albicans, a major human fungal pathogen. J Microbiol 2011; 49: 171-177.

Levison ME. Pharmacodynamics of antibacterial drugs. Infectious Diseases of North America 2000; 14: 281-291.

Levy SB. Antibiotic resistance-the problem intensifies. Adv Drug Deliv Rev 2005; 57: 1446-1450.

Liang $\mathrm{H}$, Xing $\mathrm{Y}$, Chen J, Zhang D, Guo S, Wang C. Antimicrobial activities of endophytic fungi isolated from Ophiopogon japonicus (Liliaceae). BMC Complement Alter Med 2012; 12(238):1-6.

Luo Y, Wang J, Liu B, Wang Z, Yuan Y, Yue T. Effect of yeast cell morphology, cell wall physical structure and chemical composition on patulin adsorption. PLOS ONE 2015; 10(8): e0136045.

Madigan M, Martinko J, Dunlap P, Clark D. 2009. Biology of Microorganisms 12th Edition. Unit 1. Pg. 81

Mares D. Electron microscopy of Microsporum cookie after in vitro treatment with protoanemonin: A combines SEM and TEM study. Mycopathol, 1989; 108: 37-46.

Nguyen T, Fleet G, Rogers P. Composition of the cell walls of several yeast species. Appl Microbiol Biotechnol, 1998; 50: 206-212.

Papon N, Courdavault V, Clastre1 M, Bennett RJ. Emerging and emerged pathogenic Candida species: beyond the Candida albicans paradigm. PLOS Pathogens, 2013; 9(9):1003550.

Pfeiffer CD, Garcia-Effron G, Zaas AK, Perfect JR, Perlin DS, Alexander BD. Breakthrough invasive candidiasisin patients on microfungin. J Clin Microbiol, 2012; 48: 2373-2380.

Quindos G. Epidemiology of candidaemia and invasive candidiasis: A changing face. Rev Iberoam Microbiol, 2014; 31: 42-48. Selitrennikoff Claude P. Fungal Protein. Appl Environ Microbiol, 2001; 67(7): 2883-2894.

Strobel GA. Endophytes as sources of bioactive products. Microb Infect 2003; 5: 535-544.

Sudbery PE. Growth of Candida albicans. Nat Rev Microbiol 2011, 9: 737-748

Tan RX, Zou WX. Endophytes: a rich source of functional metabolites. Nat Prod Rep 2001; 18(4): 448-459.

Tong WY, Chong CL, Darah I, Latiffah Z. Enhancement of anticandidal activity of endophytic fungus Phomopsis sp. ED2, isolated from Orthosiphon stamineus Benth, by incorporation of host plant extract in culture medium. J Microbiol 2012; 50(4): 581-585.

Tong WY, Leong CR, Tan WN, Melati K, Latiffah Z, Darah I. Endophytic Diaporthe sp. ED2 produces a novel anti-candidal keton derivative. J Microbiol Biotechnol 2017; 27(6):1065-1070.

Wiegand I, Hilpert K, Hancock REW. Agar and broth dilution methods to determine the minimal inhibitory concentration (MIC) of antimicrobial substances. Nat Prot 2008; 3(2):163-175.

Xiang MJ, Liu JY, Ni PH, Wang S, Shi C, Wei B. Erg11 mutations associated with azole resistant in clinical isolates of Candida albicans. FEMS Yeast Res 2013; 13: 386-393.

Yan XN, Sikora IR, Zheng JW. Potential use of cucumber (Cucumis sativus L.) endophytic fungi as seed treatment agents against root-knot nematode Meloidogyne incognita. J Zhejiang Uni Sci B 2011; 12:219-225.

Yapar N. Epidemiology and risk factors for invasive candidiasis Therapy Clin Risk Manag 2014; 10: 95-105.

Yu H, Zhang L, Li I, Zheng C, Guo I, Li W, Sun P, Qin I. Recent developments and future prospects of antimicrobial metabolites produced by endophytes. Microbiol Res 2010; 165: 437-449.

How to cite this article:

Ibrahim D, Nurhaida, Hong LS, Anti-candidal activity of Aspergillus flavus IBRL-C8, an endophytic fungus isolated from Cassia siamea Lamk leaf. J App Pharm Sci, 2018; 8(02): 083-087. 